$$
\begin{aligned}
& \text { الَوهاى ير اكنش Fونه هاى بخشه هييو Fلو تيدهاى از سرده Fون (تيره باقالئيان) در } \\
& \text { ايران } \\
& \text { على باقرى'، محمد محمودى ب و على اصغر معصومى' }
\end{aligned}
$$

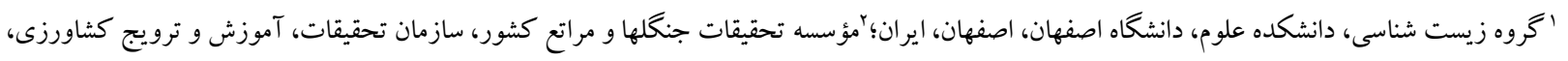

$$
\begin{aligned}
& \text { تهران، ايران } \\
& \text { mahmoodi@ rifr-ac.ir مسئول مكاتبات: محمد محمودى، }
\end{aligned}
$$

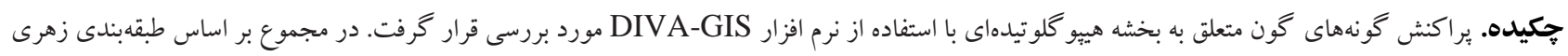

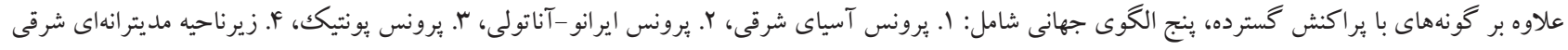

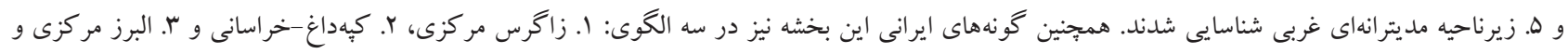

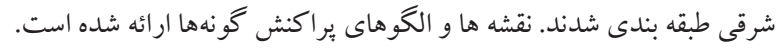

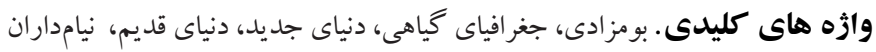

\title{
The distribution patterns of Astragalus sect. Hypoglottidei DC. (Fabaceae) in Iran
}

\section{Ali Bagheri', Mohammad Mahmoodi ${ }^{2}$ \& Ali Asghar Maassoumi ${ }^{2}$}

${ }^{1}$ Department of Biology, Faculty of Sciences, University of Isfahan, Isfahan, Iran; ${ }^{2}$ Botany Research Division, Research Institute of Forests and Rangelands, Agricultural Research, Education and Extension Organization (AREEO), Tehran, Iran

Correspondent author: Mohammad Mahmoodi, mahmoodi@rifr-ac.ir

\begin{abstract}
The distribution patterns of taxa belonging to the section Hypoglottidei DC. were investigated using DIVAGIS software. Based on Zohary classification, five global patterns, with the exception of widely distributed species, include 1. Centro-Asiatic province, 2. Irano-Anatolian province, 3. Pontic province, 4. East Mediterranean subregion and 5. West Mediterranean subregion, were identified. In addition, the Iranian species of this section were classified in three patterns: 1. Central Zagros 2. Khorasan-Kopet Dagh 3. Central and Eastern Alborz. The maps and distribution patterns of the species were also presented.
\end{abstract}

Keywords. endemism, legumes, New World, Old World, phytogeography 


\section{INTRODUCTION}

Astragalus L. (Fabaceae), with more than 3000 species, is the largest genus of vascular plants (Podlech $\&$ Zarre, 2013). Astragalus is also the largest genus in Iran with around 826 species (Ghahremaninejad, 2015), comprising more than $11 \%$ of Iran's flora (Ghahremaninejad et al., 2012). Among 240 sections of this genus, only few sections occur in both the Old World and New World (Barneby, 1964; Podlech \& Zarre, 2013). Sect. Hypoglottidei DC. is one of the complicated sections of Astragalus with a total of 46 species, having members in both the Old and the New Worlds. In fact, the type species of this section is Astragalus hypoglottis L., which was selected by De Candolle (1825), and later the species were selected by Podlech (1990) as lectotype. Sect. Hypoglottidei is one of the medium-sized sections within the genus (Mahmoodi et al., 2012). Turkey, with 19 species (Podlech \& Zarre, 2013), and Iran, with 11 species (Maassoumi, 2018), are the centers of diversity of this section in the Old World. About $82 \%$ of the Iranian taxa belonging to this section are endemic to the country (Maassoumi, 2018). The members of this section are herbaceous, characterized by diagnostic morphological features such as tubular calyx and filiform teeth, which are shorter than the tube, long and erect petals, as well as distinctly incised wing apices. This section has been taxonomically revised several times during the last decades (Maassoumi, 1988, 1989, 2018; Chamberlain \& Matthews, 1970; Podlech et al., 2010; Xu \& Podlech, 2010; Podlech \& Zarre, 2013). Based on recent molecular phylogenetic analyses on the genus (Kazempour Osaloo et al., 2003, 2005) sect. Hypoglottidei is not a monophyletic group.

To understand the origin of a taxon, as well as its migration pattern in space and time, precise information, including fossil records and absence/presence occurrence data, is needed (LunaCavazos, \& Bye, 2011). However, adequate information to elucidate these evolutionary aspects of sect. Hypoglottidei is not available. Yet, we illustrated the geographic distribution pattern of sect. Hypoglottidei by presenting the current knowledge of the section's worldwide range and its main diversity centers. We did this by using georeferenced specimen records from natural history collections. Taking into account the distribution of Astragalus, a distinct geographical disjunction between the New and Old Worlds species can be observed. In this study, we provided an update of the geographical distribution of sect. Hypoglottidei.

\section{MATERIALS AND METHODS}

In order to provide a global distribution pattern of sect. Hypoglottidei, a dataset was compiled using standard Flora accounts (Podlech et al., 2010;
Chamberlain \& Matthews, 1970; Xu \& Podlech, 2010) and a recent revision of the genus Astragalus in the Old World (Podlech \& Zarre, 2013). Distribution data for North America was obtained from USDA plant database (USDA, 2018). Also, accounts of species distributions for North America came from Atlas of North American Astragalus (Barneby, 1964). Global Biodiversity Information Facility (GBIF) (GBIF, 2018) was consulted in some cases. Locations of all of the species, as reported in the literature, were georeferenced, and the distribution range of the species studied was mapped using DIVA-GIS (Hijmans et al., 2005). Because the analysis in this study follows Zohary's classification (Zohary, 1973), his phytogeographical map was digitized using DIVA-GIS. By overlying the georeferenced records on the digital map, we analyzed the distribution patterns of sect. Hypoglottidei.

\section{RESULTS}

\section{Distributional pattern of sect. Hypoglottidei}

Based on Podlech \& Zarre (2013), 45 out of 46 species of this section occur exclusively in the Old World, and the only native representative species in the New World is Astragalus agrestis Douglas ex G. Don. This species has an additional distribution center in Asia (Fig. 1), which indicates a transBeringean colonization of North America. Astragalus cicer L. is frequently recorded in the New World, but was introduced there by human beings (Podlech \& Zarre, 2013). Among the Old World species belonging to this section, Astragalus danicus Retz. is the most widespread species, distributed throughout nearly the entire northern part of the Old World. Astragalus agrestis, A. cicer, and A. danicus can be considered to be widespread species (Fig. 1). Mapping distributional data by DIVA-GIS clearly showed that the remaining species putatively belonging to sect. Hypoglottidei fall into five distinct phytogeographical units according to Zohary (1973): 1. Centro-Asiatic province, 2. Irano-Anatolian province, 3. Pontic province, 4. East Mediterranean subregion, and 5. West Mediterranean subregion (Fig. 2). In this pattern, regions 1-5 have considerable numbers of endemics and it can be assumed that the rates of speciation in these areas are high, although, this is only an estimation without the support of comparative analyses.

\section{DISCUSSION}

The Irano-Anatolian and Pontic provinces are the most important centres of diversity of section Hypoglottidei based on their high endemism and species richness. The base chromosome number for 

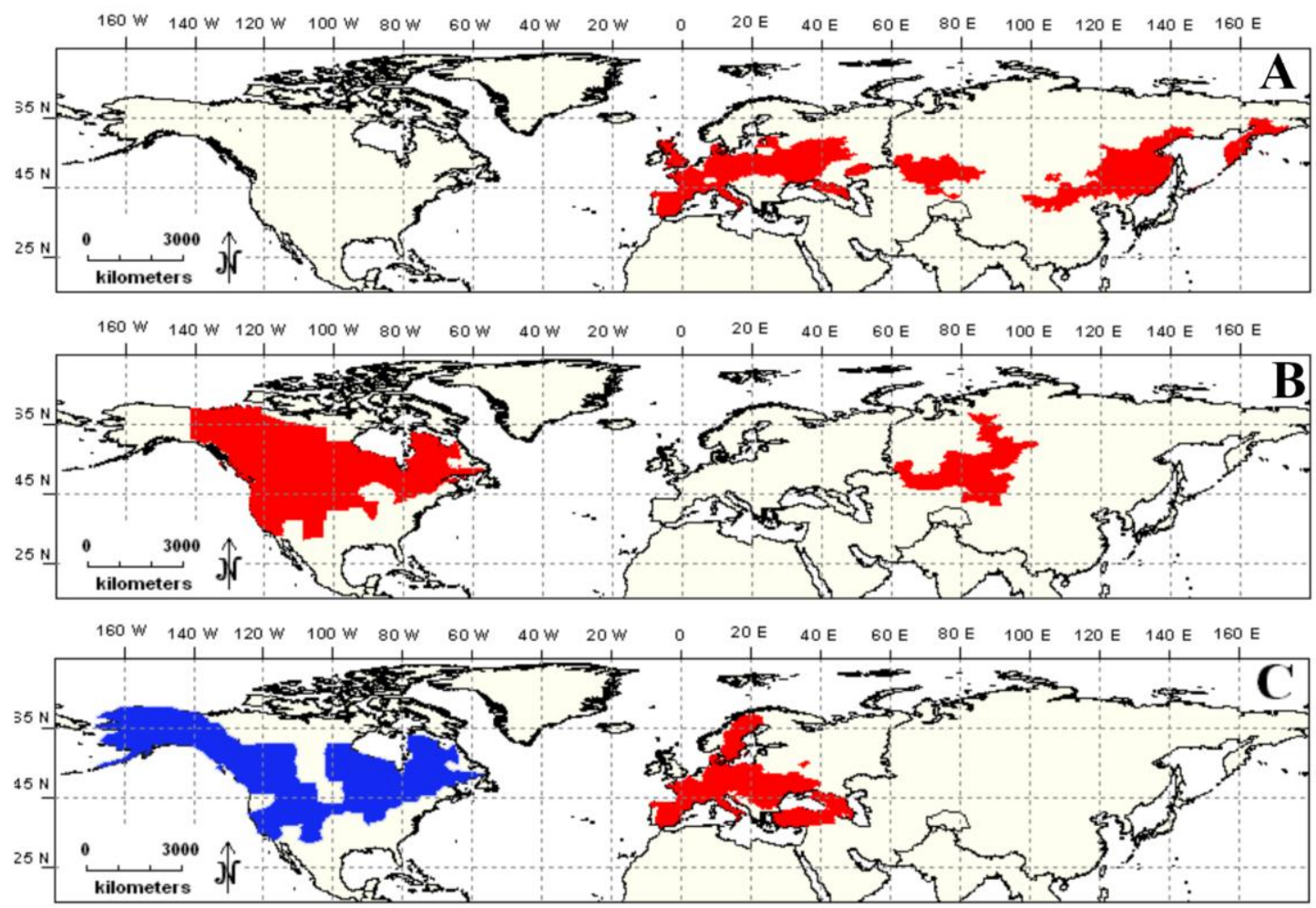

Fig. 1. Distribution of widespread species of sect. Hypoglottidei. A. A. danicus. B. A. agrestis. C. A. cicer: native (red), introduced (blue).

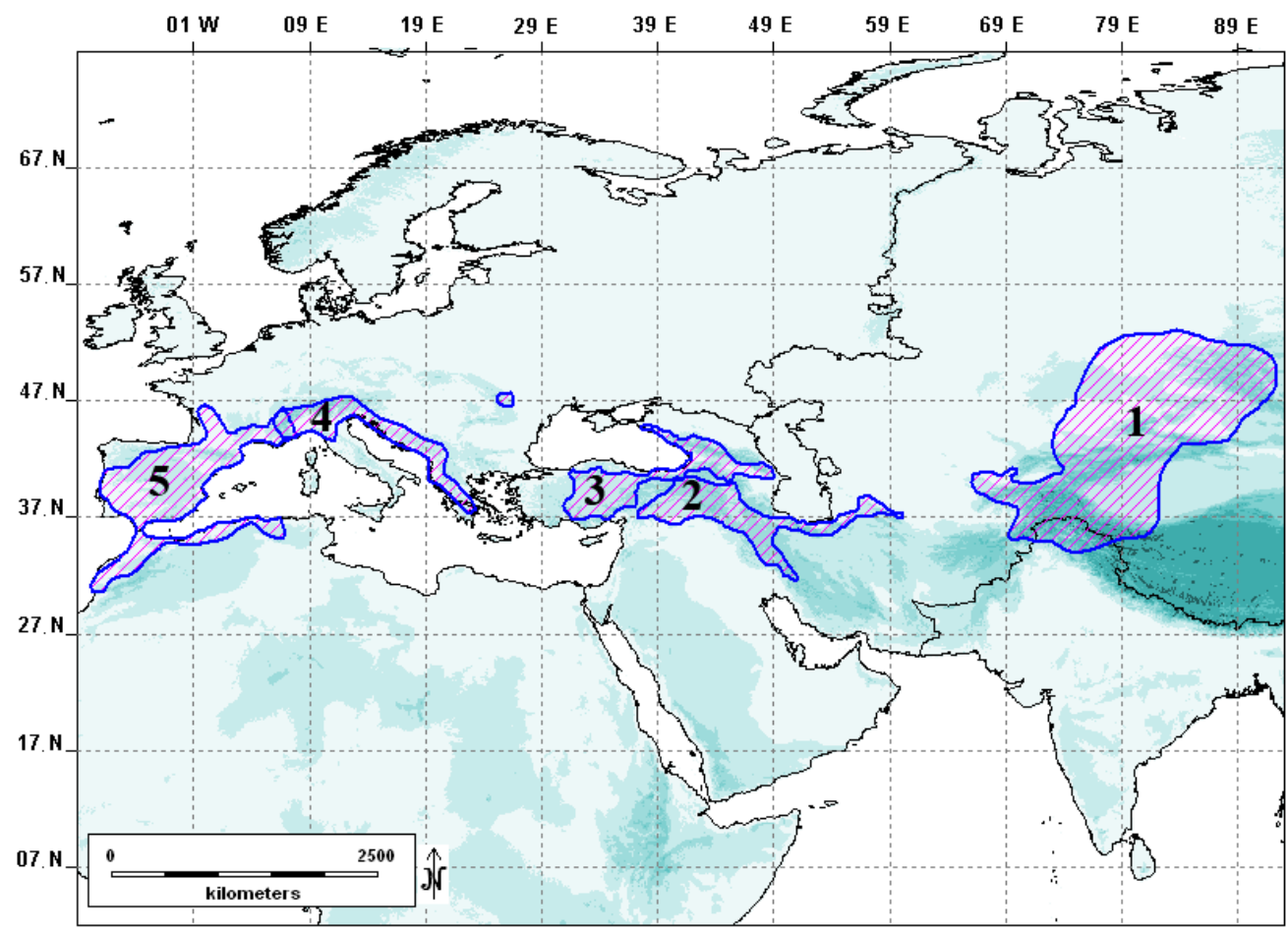

Fig. 2. Distribution of Astragalus sect. Hypoglottidei (except A. danicus, A. agrestis, and A. cicer) in the Old World. 1: Centro-Asiatic species, 2- Irano-Anatolian species, 3- Pontic species, 4: East Mediterranean species and 5- West Mediterranean species. 

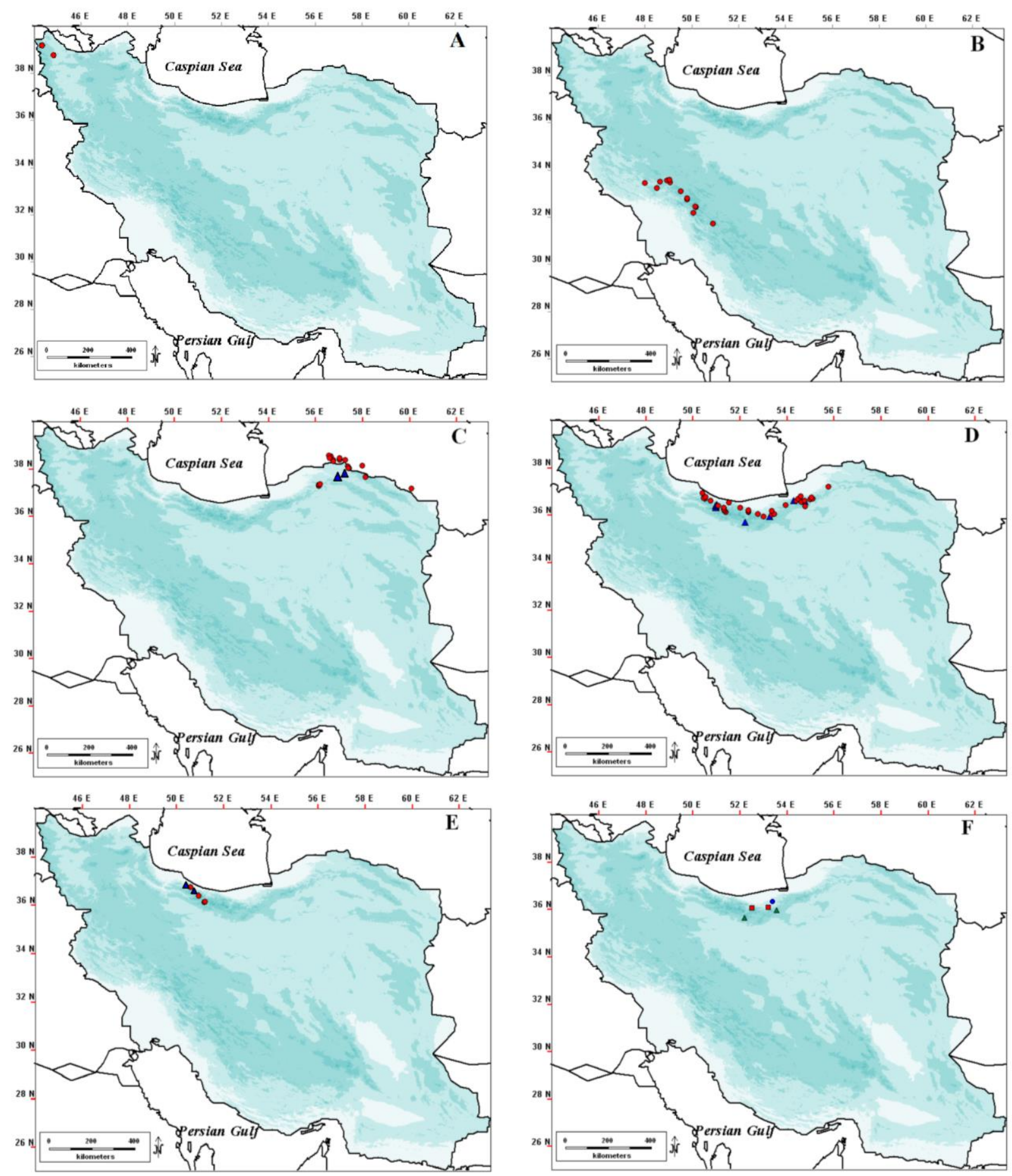

Fig. 3. Distribution maps of species of sect. Hypoglottidei in Iran. A. A. saganlugensis. B. A. longirostratus. C. A. brachypetalus $(\bullet)$ and A. bojnurdensis $(\mathbf{\Delta})$. D. A. atricapillus $(\boldsymbol{\Delta})$ and A. nurensis $(\bullet)$. E. A. rimarum $(\bullet)$ and A. pishchakensis $(\mathbf{\Delta})$. F. A. herbertii $(\bullet)$, A. damghanensis $(\bullet)$ and A. parvarensis $(\mathbf{\Delta})$.

the genus is $x=8$. The majority of New World species are aneuploid but 13-15 species in North America have euploid or polyploid chromosome numbers based on $\mathrm{x}$ $=8$. Astragalus agrestis and A. cicer have not been considered or treated as aneuploids (Wojciechowski et al., 1993). According to Podlech \& Zarre (2013) A. cicer was introduced to and naturalized in America while A. agrestis is a native species in North America.
We suggest that it can be a recent colonization (not an introduction) from the Old World to the New World, for which many examples are reported (e.g., Blattner \& Kadereit, 1995; Blattner, 2006; Friesen $\&$ Blattner, 2000). The general distribution patterns of sect. Hypoglottidei (Fig. 2) can be interpreted as having arisen through a process of vicariance, whereby four assemblages were formed. These 
vicariant assemblages were formed by adaptation to the highlands and semi-desert areas of the northeast of Iran, the highlands and mountains of Azarbayejan and the disjunction between Asia and Europe across the Black Sea and the Aegean Sea. At the moment, there is no sufficient evidence to explain the evolutionary mechanism(s) shaping the abovementioned distribution patterns of sect. Hypoglottidei and it is hard to imagine the kind of event(s) which may have caused these patterns.

\section{Distribution of section Hypoglottidei in Iran}

All the Iranian species belonging to sect. Hypoglottidei should be considered Irano-Anatolian elements, except $A$. longirostratus, which is clearly a Kurdo-Zagrosian species. Nearly all other species fall into the Armeno-Iranian Sector (Zohary, 1973). Without following traditional phytogeographical classification, and only on the basis of their geographical distribution, Iranian species can be subdivided into three groups:

\section{Species distributed across Central Zagros Mountains:}

A. longirostratus $\mathrm{Pau}$ is the only species in this area (Fig. 3B) and is the southernmost species in the distribution range of sect. Hypoglottidei. It is distributed in Chaharmahal va Bakhtiari, Isfahan and Lorestan Provinces.

\section{Species distributed across Khorasan-Kopet Dagh Mountains:}

A. brachypetalus Trautv. and A. bojnurdensis Podlech are two members of this group (Fig. 3C). A. brachypetalus is presented in many collections on both sides of the border of Iran (north-eastern part of the country mainly from North Khorasan Province) and Turkmenistan, but especially on the Turkmenistan side, whereas A. bojnurdensis is a local endemic species in the area.

\section{Species distributed across central and eastern Alborz Mountains:}

The species in this group can be subdivided into three subgroups: a. A. atricapillus Bornm. and A. nurensis Boiss. \& Buhse (Fig. 3D), which have a rather wide distribution in Golestan, Mazandaran, Semnan and Tehran Provinces, the latter being the most widespread of the Iranian species in the section. b. A. rimarum Bornm. and A. pishchakensis Maassoumi (Fig. 3E) are the westernmost central species of the Alborz subgroup. Both species are local endemic and represented by limited records in Mazandaran and Tehran Provinces. c. A. herbertii Maassoumi (occurs only in Mazandaran Province) and A. parvarensis Podlech \& Sytin and A. damghanensis Podlech (occur only in Semnan Province) (Fig. 3F), which comprise the easternmost central Alborz subgroup. The other species found in Iran is A. saganlugensis Trautv. (Fig. 3A). This species mainly occurs in East Anatolia and Southern Caucasus. The first record of this species for the flora of Iran is that of Szovits in 1828 (Lamond, 1973) and the second and most recent one rediscovered by Bagheri et al. (2018).

\section{ACKNOWLEDGEMENT}

This study was carried out with the financial support of the University of Isfahan and the Research Institute of Forests and Rangelands of Iran.

\section{REFERENCES}

Bagheri, A., Maassoumi, A.A. and Vitek, E. 2018. Rediscovery of Astragalus saganlugensis (Fabaceae, Galegeae) in Iran after 184 years. - Phytotaxa 350: 297-299.

Barneby, R.C. 1964. Atlas of north American Astragalus. - Memoirs of the New York Botanical Garden 13: 11188 .

Blattner, F.R. 2006. Multiple intercontinental dispersals shaped the distribution area of Hordeum (Poaceae). New Phytol. 169: 603-614.

Blattner, F.R. and Kadereit, J.W. 1995. Three intercontinental disjunctions in Papaveraceae subfamily Chelidonioideae: Evidence from chloroplast DNA. - Plant Syst. Evol. [Suppl.] 9: 147157.

Candolle, A.P. de 1825. - Prodromus systematis naturalis regni vegetabilis. 2. 281 pp. Paris.

Chamberlain, D.P. and Matthews, V.A. 1970. Astragalus L. - In: Davis, P.H. (ed.) Flora of Turkey and the East Aegean Islands 3: 49-254. - Edinburgh University Press. Edinburgh.

Friesen, N. and Blattner, F.R. 2000. RAPD analysis reveals geographic differentiations within Allium schoenoprasum L. (Alliaceae). - Plant Biology 2: 297-305.

GBIF 2018. Global Biodiversity Information Facility. http://www.gbif.org [accessed 18 Nov 2018].

Ghahremaninejad, F. 2015. Notes about Astragalus (Leguminosae) in Iran. - Ann. Naturhist. Mus. Wien 117B: 117: 279-281.

Ghahremaninejad, F., Bagheri, A. and Maassoumi, A.A. 2012. Two new species of Astragalus L. sect. Incani DC. (Fabaceae) from the Zanjan province (Iran). Adansonia 34: 59-65.

Hijmans, R.J., Guarino, L., Bussink, C., Mathur, P., Cruz, M., Barrantes, I. and Rojas, E. 2005. DIVAGIS, Version 5: A geographic information system for the analysis of biodiversity data [Software]. International Plant Genetic Resources Institute (IPGRI): Available from: http://diva-gis.org.

Kazempour Osaloo, S., Maassoumi, A.A. and Murakami, N. 2003. Molecular systematic of the genus Astragalus L. (Fabaceae): Phylogenetic analyses of 
nuclear ribosomal DNA internal transcribed spacers and chloroplast gene ndhF sequences. - Plant Syst. Evol. 242: 1-32.

Kazempour Osaloo, S., Maassoumi, A.A. and Murakami, N. 2005. Molecular systematics of the Old World Astragalus (Fabaceae) as inferred from nrDNA ITS sequence data. - Brittonia 57: 367-381.

Lamond, J.M. 1973. The Transcaucasian and Iranian collections of J.N. Szovits. - Notes Roy. Bot. Gard. Edinburgh 32: 239-245.

Luna-Cavazos, M. and Bye, R. 2011. Phytogeographic analysis of the genus Datura (Solanaceae) in continental Mexico. - Rev. Mex. Biodiv. 82: 977-988.

Maassoumi, A.A. 1988. Revision of Astragalus L. sect. Hypoglottidei DC. in Iran. - Mitt. Bot. Staatssamml. Münch. 27: 125-133.

Maassoumi, A.A. 1989. The genus Astragalus in Iran, vol. 2. 386 pp. - Research Institute of Forests and Rangelands. Tehran.

Maassoumi, A.A. 2018. Fabaceae: Astragalus III. - In: Assadi et al. (eds.) Flora of Iran, No. 145. 766 pp. Research Institute of Forests and Rangelands, Tehran.

Mahmoodi, M., Maassoumi, A.A. and Jalili A. 2012. Distribution patterns of Astragalus in the Old World based on some selected sections. - Rostaniha 13: 3956.

How to cite this article:

Bagheri, A., Mahmoodi, M. and Maassoumi, A.A. 2019. The distribution patterns of Astragalus sect. Hypoglottidei DC. (Fabaceae) in Iran. - Nova Biol. Reperta 6: 320-325.

Podlech, D. 1990. Die Typifizierung der altweltlichen Sektionen der Gattung Astragalus L. (Leguminosae). - Mitt. Bot. Staatssamml. Münch. 29: 478.

Podlech, D. and Zarre, Sh. (with collaboration of Ekici, M., Maassoumi, A.A. and Sytin, A.). 2013. A taxonomic revision of the genus Astragalus L. (Leguminosae) in the Old World. Vols. 1-3. 2439 pp. Naturhistorisches Museum, Wien.

Podlech, D., Zarre, Sh., Maassoumi, A.A., Ekici, M. and Sytin, A. 2010. Papilionaceae VI: Astragalus L. IV \& Barnebyella Podlech. - In: Rechinger K.H. (ed.) Flora Iranica, No. 178. 430 pp. - Akad. Druck- und Verlagsanstalt, Graz.

USDA, NRCS. 2018. The PLANTS Database (http://plants.usda.gov,). National Plant Data Team, Greensboro, NC 27401-4901 USA. [Accessed: 10 Nov. 2018].

Wojciechowski, M.F., Sanderson, M.J., Baldwin, B.G. and Donoghue, M.J. 1993. Monophyly of aneuploid Astragalus (Fabaceae): Evidence from nuclear ribosomal DNA internal transcribed spacer sequences. - Am. J. Bot. 80: 711-722.

Xu, L. and Podlech, D. 2010. Astragalus L. - In: Wu, Z.Y. and Raven, P.H. (eds.) Flora of China 10: 328453. - Harvard University Herbaria.

Zohary, M. 1973. Geobotanical foundations of the Middle East. - Fischer, Stuttgart, 340 pp.

$* * * * *$ 